\title{
INHIBITION OF DIFFUSION CONTROLLED CORROSION IN EQUIPMENT HANDLING PULP SLURRY
}

\author{
Olfat A. Fadali ${ }^{1}$, Mamdouh M. Nassar ${ }^{1}$, Ebrahim H. Mahmoud ${ }^{1}$ \\ Omnia H. Abdelraheem ${ }^{2}$, Sara K.Mohamed ${ }^{1}$ \\ ${ }^{1}$ Chemical Engineering Department, Faculty of Engineering, Minia University, El-Minia, Egypt \\ ${ }^{2}$ Basic Engineering Sciences Department, Faculty of Engineering, Beni-Suef University, Egypt
}

\begin{abstract}
:
Corrosion of the wall of an agitated vessel containing pulp-fiber suspensions was studied using an accelerated test which involves the diffusion controlled dissolution of copper in acidified dichromate. Variables studied were pulp slurry flow rates, slurry concentrations and pulp fiber size. Three different pulp sizes were studied, namely: fiber-pulp slurry, fine-pulp slurry and the whole-pulp slurry. The rate of mass transfer controlled corrosion of copper was found to increase with increasing slurry flow rate and decreased by increasing pulp slurry concentrations. Fines in pulp slurry were found to play a major role in decreasing the rate of diffusion controlled corrosion due to its ability to damp small scale eddies at the wall of the agitated vessel in a manner similar to drag reducing polymers in pipes. Percentage inhibition efficiency using fine- pulp slurry ranged from $40 \%$ to $76 \%$, while for the whole-pulp slurry the value ranged from $28 \%$ to $47 \%$, when pulp slurry concentration ranged from $0.1 \%$ to $0.4 \%$.
\end{abstract}

Keywords: Pulp slurry transportation, Drag reduction, Diffusion controlled corrosion.

\section{INTRODUCTION:}

The flow of pulp-fiber suspension occurs in most of the operations encountered in pulp and paper manufacture. The hydrodynamic properties of the pulp fiber suspension are different from that of water (Newaz-zaki,et.al 1999). Pulp-fiber suspension even at low concentration interact and entangle to form three dimensional coherent network and produce a plug flow of coherent network occupy the center of the pipe (Vaseleski and Metzner, 1974). The main part of the shear occurred in the boundary layer which exist at the pipe wall (Steenberg, etal 1960). Several mechanisms have been given based on study the transport properties and turbulence on the behavior of pulp suspension flow

Received: 15 November, 2019, Accepted: 9 December, 2019
(Huhtanen and Karvinen, 2005; Steenberg et al, steenberg et.al, 1960; Robertson and Mason, 1957 and Higgins and Wahern, 1982). At low flow rate, the layer between the plug and the pipe wall is thin and the frictional resistance is greater than that of water alone but at higher flow rates, fibers pulled out from the plug pulp-fiber network and modify eddy formation and dissipated near the wall and thus damp turbulence. At very high flow rates the fiber suspensions friction factor values drops to levels near, or even below these of water (Vaseleski and Metzener, 1974).At this end, fiber suspension, according to Hoyt (1972) exhibit very appreciable drag reducing effect.

Flow of pulp slurry can affect the rate of steel pipelines corrosion in many ways, to explain the mechanism by which pulp slurry can affect the rate of corrosion, the 
mechanism of corrosion should be reviewed first (Fontana ,1987). Steel corrosion takes place through the formation of a galvanic cell between its more noble phase $\mathrm{Fe}_{3} \mathrm{C}$ (cementite) and its less noble phase $\mathrm{Fe}$ (ferrite)

$\mathrm{Fe} /$ electrolyte / $\mathrm{Fe}_{3} \mathrm{C}$

Cell reactions:

Anode $(\mathrm{Fe}): \quad \mathrm{Fe}=\mathrm{Fe}^{++}+2 \mathrm{e}$

Cathode $\left(\mathrm{Fe}_{3} \mathrm{C}\right): \quad 2 \mathrm{H}^{+}+2 \mathrm{e}=\mathrm{H}_{2}(\mathrm{pH} 4)$

Or

$$
1 / 2 \mathrm{O}_{2}+\mathrm{H}_{2} \mathrm{O}+2 \mathrm{e}=2 \mathrm{OH}^{-} \quad(\mathrm{pH} 4-10)
$$

Side reaction: $\mathrm{Fe}^{++}+2 \mathrm{OH}^{-}=\mathrm{Fe}(\mathrm{OH})_{2}$

$\mathrm{Fe}(\mathrm{OH})_{2}$ undergoes oxidation with dissolved oxygen to give a porous oxide film on the steel surface. The porous oxide film allows further corrosion to take place (Schmitt and Bakalli, 2008).

In industry the $\mathrm{pH}$ ranges mostly from 4-10, accordingly dissolved oxygen reduction takes place as a cathodic reaction. Previous studies (Fontana, 1987) have revealed that the rate of steel corrosion in the $\mathrm{pH}$ range 410 is controlled by the rate of dissolved oxygen diffusion from the solution bulk to the corroding surface.

Pulp slurry can decrease the rate of steel corrosion by either decreasing the diffusivity of dissolved oxygen or by damping the small scale eddies which accelerate the rate of mass transfer of dissolved oxygen to the corroding surface under turbulent flow conditions. In view of the slowness of steel corrosion by dissolved oxygen an accelerated test was used in the present work which simulates natural corrosion, namely the diffusion controlled dissolution of copper in acidified $\mathrm{K}_{2} \mathrm{Cr}_{2} \mathrm{O}_{7}$ ( Fontana,1987 and Sedahmed et. al, 2004 ). The system has been used widely to study diffusion controlled corrosion (Sedahmed et.al, 2004, Greggory and Riddiford, 1960 and Abdel-Aziz, 2013).
The aim of this study is to investigate the effect of pulp-fiber components (fiber-pulp slurries, fines-pulp slurries and whole- pulp slurries) on the rate of corrosion in agitated vessel using the diffusion controlled dissolution of copper in acidified dichromate technique. Although the present results were obtained using an agitated vessel, the results can be extended to pipelines carrying pulp slurries under turbulent flow at least quantitatively. Agitated vessels are used in paper industry to mix different ingredients e.g. bleaching agents, sizing material, etc. with the pulp slurry.

\section{EXPERIMENTAL WORK}

\subsection{Apparatus}

The experimental unit used in the present work is shown in fig .1. The unit consisted mainly of cylindrical glass vessel of $11.8 \mathrm{~cm}$ diameter and $14.7 \mathrm{~cm}$ height, with a sheet of copper lining the inside wall of the glass vessel. The solution ( $9 \mathrm{~cm}$ height) was stirred with an agitator which consisted of stainless steel shaft fitted with $45^{\circ}$ pitched of turbine 5 $\mathrm{cm}$ diameter. The shaft and turbine were coated with epoxy resin. The shaft was driven by a 0.5 horse power variable speed motor. Impeller rotational speed was controlled by means of a variac and was measured by an optical tachometer. Rotational speed ranged from 50 to 400 r.p.m.

\subsection{Materials}

Copper dissolution in acidified dichromate is known to be diffusion controlled reaction (Greggory and Riddiford, 1960). This technique is simple, therefore it widely used to study liquid-solid mass transfer under different hydrodynamic conditions (Patil and Shama, 1983 and Gruber and Melin, 2003). The solution used in this study consists of acidified potassium dichromate with the following composition : $\left(0.003 \mathrm{M} \mathrm{K} \mathrm{K}_{2} \mathrm{Cr}_{2} \mathrm{O}_{7}+0.5 \mathrm{M} \mathrm{H}_{2} \mathrm{SO}_{4}\right)$, and bleached bagasse pulp slurry was added at different concentrations $(0.1 \%, 0.2 \%, 0.3 \%$ and $0.4 \%$ ) . 
The used pulp slurry was obtained from Misr Edfu Pulp Writing and Printing Paper Company (MEPPCO). The pulp produced from cooking of bagasse by alkaline process (Kraft pulping) and bleached by three stages (oxygen, chlorine dioxide and peroxide).

Fiber pulp classification was carried out by Baur Mc-Mett classifier using 100-mesh screen. The pulp retained above 100-mesh screen was considered fiber-pulp slurry and that passed the 100- mesh screen was considered as fine- pulp slurry, therefore, three types of pulp slurries were used namely; fine- pulp slurry, fiber- pulp slurry and whole-pulp slurry.

Microscopic examination for bagasse components was carried out using Optical Microscope, Amscope 40X-2000X.

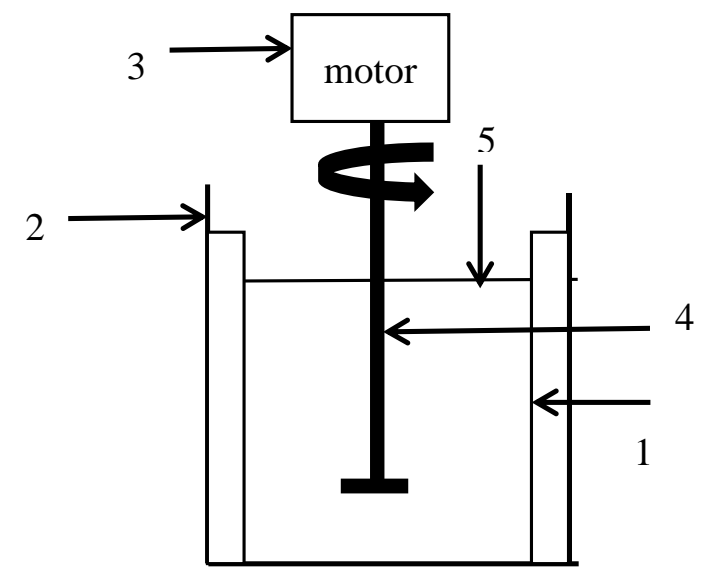

Fig.1. Schematic diagram of the experimental setup.

1: copper cylindrical sheet. 2- 1L glass container. 3-variable speed digital motor. 4: $45^{\circ}$ pitched turbine impeller. $5-$ solution level.

\subsection{Procedure}

The experiment was carried out at room temperature $\left(24^{\circ} \mathrm{C}\right)$. The rate of copper dissolution in acidified dichromate solution was followed by withdrawing $5 \mathrm{~cm}^{3}$ samples at 3 minutes intervals for dichromate analysis. Dichromate was analyzed by using a UV- visible Spectrophotometer (Shimadzu Model: $1601 \mathrm{UV}$ ) at $352 \mathrm{~nm}$ wave length .

\section{RESULTS AND DISCUSSIONS}

\subsection{Pulp structure}

Bagasse pulp is made from bagasse (bagasse is the solid residue that remain after extraction of sugar from sugarcane). According to Rydholm (1967) and Nassar(1975) bagasse is composed of different cellulosic materials such as fiber, vessel cells and pith cells all are intermixed, therefore bagasse pulp is composed of fibers and fines (fines in bagasse pulp is mainly small parts from broken pith cells).

Figure (2-4) shows micrograph of bagasse. Figure (2) shows the mixture of all cellulosic materials, on top left hand of the picture there is a vessel cell, the long dark stiff lines are fibers and all other small parts dispersed in the graph are parts from broken pith cells. Figure (3-4) show pith cells in different orientation, it can be noticed how they are very thin, therefore easily broken down to small parts during pulping and is considered as fines. According to Nassar, (1975) and Rydholm, (1967) bagasse consists of $65 \%$ fiber fraction ( fiber and vessel ) and 35\% pith cell, after depith $20-18 \%$ of pith remain in bagasse (Nassar, 1975, and Misr Edfo Company, 2018).

At this end, bagasse pulp is considered as a mixture of fibers and fines .According to Ronald, (1969) pulp slurries passes 100-mesh screen are considered fines and that retained on the 100-mesh is fiber fraction. In this study it was found that $22.1 \%$ of fines passed 100 mesh screen and $77.9 \%$ retained on 100 mesh and considered as fiber fraction (fibers in pulp slurries are flexible and easily entangled and can form coherent structure).

Three types of pulps are used, fine- pulp slurry passed 100 mesh, fiber-pulp slurry retained in100- mesh and whole- pulp slurry without screening. According to Huhtanen and Karvinen (2005), during flow of pulp slurry in pipe, fibers are interact, form coherent network and occupy the center of the pipe as plug flow. As flow rate increased, 
fines and very short fibers are detached and gathered near the wall, accordingly the three types of pulp slurries will affect differently the rate of mass transfer of dissolved oxygen and consequently the rate of corrosion.

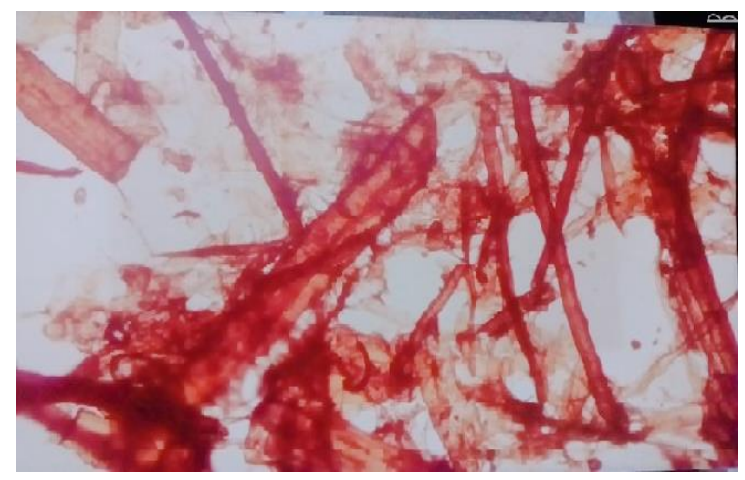

Fig.2. Mixture of all materials (fiber, vessel and pith ) $(40 \mathrm{X})$

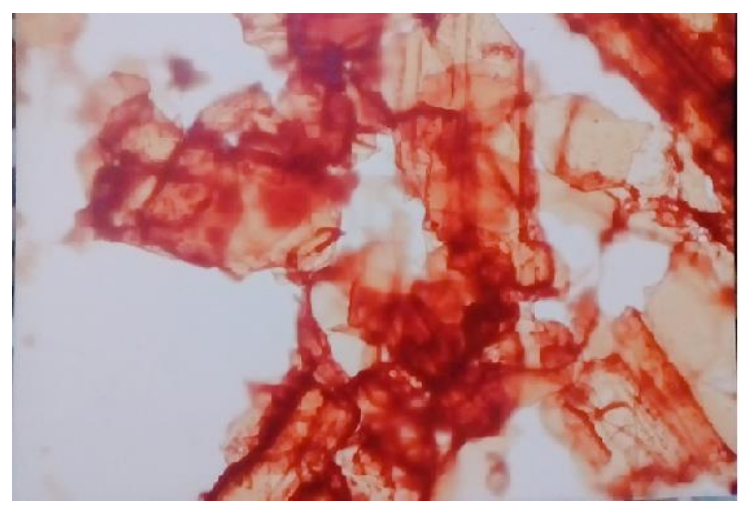

Fig.3. Longitudinal pith cells (2000 X)

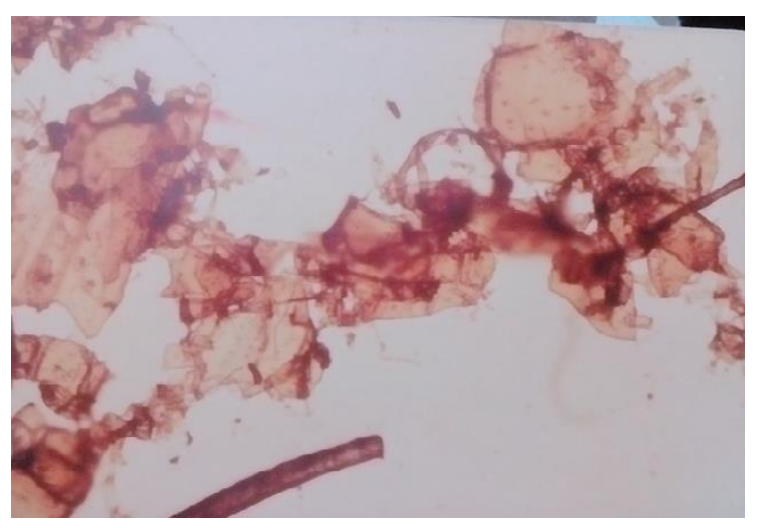

Fig.4. Broken pith cells (2000 X)

\subsection{Effect of pulp flow rate on rate of diffusion controlled of copper corrosion}

For a batch reactor, where a diffusion controlled reaction takes place, the concentration- time relation is described by the differential equation (Walsh, 1993):

$$
\frac{d C}{d t}=-\frac{K A C}{V}
$$

Upon integration

$$
V \ln \frac{C o}{C}=\text { K. A. t }
$$

Where $\mathrm{V}$ is volume of the solution, $\mathrm{cm}^{3}, \mathrm{~K}$ is a mass transfer coefficient, $\mathrm{cm} / \mathrm{s}, \mathrm{C}_{\mathrm{o}}$ and $\mathrm{C}$ are the initial concentration and concentration after time $(\mathrm{t}, \mathrm{min})$ in $\mathrm{ppm} \mathrm{A}$ is an area of copper vessel wall, $\mathrm{cm}^{2}$, respectively.

Figures (5-7) show a typical $\ln C_{0} / C$ vs. time plot for the obtained results at different agitation speed for $0.4 \%$ concentration of fiber, fine and whole pulp slurries. The present data fit equation 2 quite well the same results were observed for other pulp concentrations $(0.1,0.2$, and $0.3 \%)$. The mass transfer coefficient $(\mathrm{K})$ was obtained from the slope of $\ln \mathrm{C}_{\mathrm{o}} / \mathrm{C}$ vs. time lines, for copper dissolution in acidified dichromate solution in presence of different types of pulp slurries. It can be observed that the rate of copper dissolution increases with increase stirring this confirms that copper dissolution is diffusion controlled. The data were correlated for the three types of the studied pulps in terms of $\mathrm{K}$ and angular velocity $(\omega)$ rev. $\mathrm{s}^{-1}$.

Figures (8-10) the data fit the following equations: For whole- pulp slurry

$$
\mathrm{K} \propto \omega^{0.65}
$$

For the fiber-pulp slurry

$$
\mathrm{K} \propto \omega^{0.63}
$$

For the fine -pulp slurry

$$
\mathrm{K} \propto \omega^{0.48}
$$

Table 1: $K$ values at different concentration for the three types of pulp Suspension, r. p.m. $=400$ and $\mathrm{Ko}=0.0055 \mathrm{cms}^{-1}$ 


\begin{tabular}{|c|c|c|l|}
\hline $\begin{array}{l}\text { Conc. } \\
\begin{array}{l}\% \\
\text { pulp }\end{array}\end{array}$ & $\begin{array}{l}\text { whole-pulp } \\
\text { slurry }\end{array}$ & $\begin{array}{l}\text { Fiber-pulp } \\
\text { slurry }\end{array}$ & $\begin{array}{l}\text { Fine } \\
\text { pulp } \\
\text { slurry }\end{array}$ \\
\hline & \multicolumn{3}{|c|}{$\mathrm{K}, \mathrm{cm} / \mathrm{s}$} \\
\hline 0.1 & 0.00396 & 0.00368 & 0.0033 \\
\hline 0.2 & 0.0033 & 0.00309 & 0.0027 \\
\hline 0.3 & 0.0029 & 0.00224 & 0.0019 \\
\hline 0.4 & 0.00294 & 0.00194 & 0.0013 \\
\hline
\end{tabular}

The exponent in equations 3-5 are in the range of 0.65 to 0.48 which is consistent with the hydrodynamic boundary layer theory. The theory assumed that $\mathrm{K}$ increases with increase $\omega$ as a result of the decrease in the diffusion layer thickness (Incropera \& Dewitt, 2005). Moreover, the lower value of $\mathrm{K}$ in equation 5 , for the fine-pulp slurry can be attributed to that, at higher stirring rates short fiber and fines are pulled out from the fiber-pulp network. This result in increased viscosity in the boundary layer near the copper pipe wall and decrease the mass transfer. Also presence of fines may form a layer that can retard diffusion of the acidified dichromate to reach copper-wall and decrease corrosion of copper. Exponent of 0.65 in equation (3) for the whole pulp is higher than that given by Amin,et.al (2014) for rice straw pulp (exponent 0.51), this may be attributed to the shorter fiber length of rice straw (1.5mm, Rydholm 1967) compared to bagasse $(1.7 \mathrm{~mm}$, Nassar, 1975). The K values for whole -pulp (Equation 3) is higher than that for fine-pulp fraction (Equation 5), this may be attributed to the fact that, amount of fines incorporated within fibers network are little. In the same time long fibers are entangled together form coherent structure thus firmly entrapped fines and the very short fibers, in consequent little amount of fines will be pulled out to the boundary layer. Under such conditions diffusion of acidified dichromate will be high and $\mathrm{K}$ values will be high. On contrary the amount of fines in the fine-pulp slurry (Equation 5) are already high. During pulp flow much fines will be separated from the bulk and suspended in the boundary layer damp the small scale turbulence which prevail in the hydrodynamic boundary layer at the vessel wall and reduce $\mathrm{K}$ in a manner similar to drag reducing polymers (Hoyt, 1972 and Newaz et.al., 1999).

\subsection{Effect of pulp concentrations on rate of diffusion controlled copper corrosion}

Figures (8-10) depict that, for a given stirring rate, $\mathrm{K}$ decreases with increase pulp concentration; this can be attributed to the following:

1- On increasing pulp slurry concentration, the network strength of the fiber structure increased, form flat plug, and entrapped much of the cellulosic materials of small dimensions (fines). The physical and hydrodynamic nature of the system is changed depending on how much of cellulosic fine material pulled out to be concentered in the hydrodynamic boundary layer. Presence of fine and very short fiber in the boundary layer will obstruct the diffusion of the depolarizer i.e. decrease its diffusivity (D) with a consequent decrease in $\mathrm{K}(\mathrm{K}=\mathrm{D} / \delta$ ).

2- The small dimension cellulosic materials ( fine and short fibers) exist in the boundary layer act as drag reducer and damp the small eddies in the hydrodynamic boundary layer, this leads to increasing the diffusion layer thickness $(\delta)$ across which the chromium ions diffuses to the copperwall with a subsequent decrease in the corrosion rate.

From the data in table 1, it can be seen that fines suspended in the hydrodynamic boundary layer have considerable effect on corrosion rate of copper, due to its ability to damp the small scale eddies which prevail in the hydrodynamic boundary layer at the vessel wall. In this regard the fine-pulp act as drag reducing polymer (Hoyt, 1972).

\subsection{Inhibition efficiency of fine-pulp slurry}


Figure (11) shows the effect of fines on percentage of inhibition efficiency (\% IE) for the three pulp slurries.

$\% \mathrm{I} \mathrm{E}$ is calculated by the following equation:

$$
\% \mathrm{IE}=\left(\mathrm{K}_{\mathrm{o}}-\mathrm{K}\right) * 100 / \mathrm{K}_{\mathrm{o}}
$$

Where $\mathrm{K}_{\mathrm{o}}$ and $\mathrm{K}$ are mass transfer coefficient of blank (without pulp) and in presence of pulp respectively. The high values of \% I E of fine fraction suggested the high inhibition effect of fines on rate of copper dissolution, probably due to not only the higher percentage of fines in the boundary layer but also due to nature of fines (pith).Pith has higher hemicellulose (33.2\% of hemicellulos in pith and $30.7 \%$ in fiber, Nassar, 1975.) hemicellulose swell easily in aqueous medium and increase viscosity in consequent minimize the number of the generated small eddies during pulp flow and increase the thickness of hydrodynamic boundary layer and finally decrease $\mathrm{K}$ and decrease corrosion rate of copper.

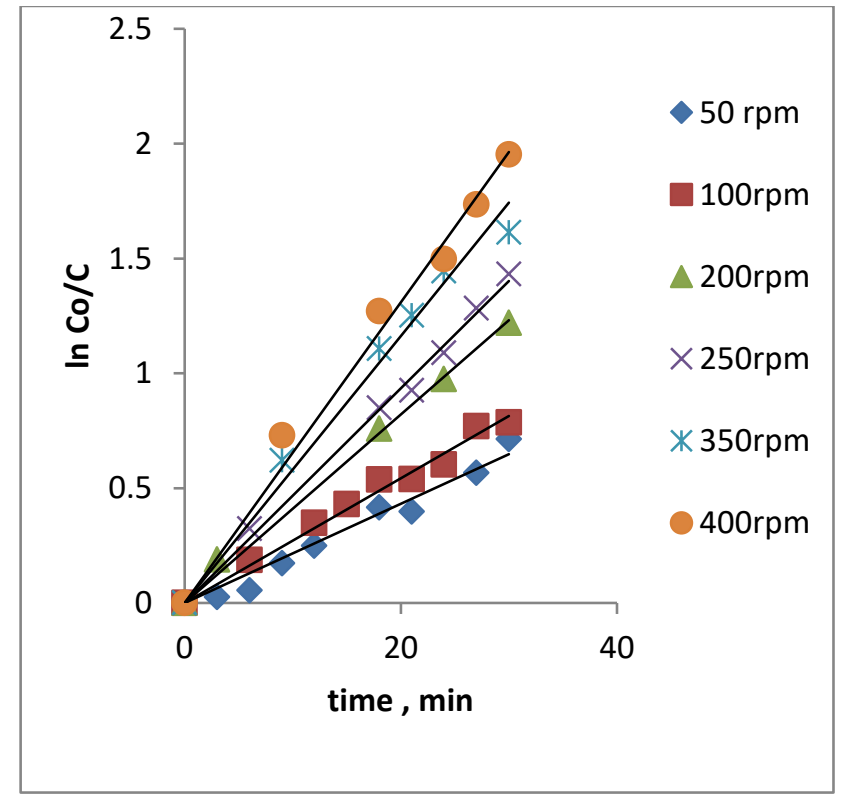

Fig.5. In Co/C vs. time for $0.4 \%$ fiber- pulp consistency at different rpm.

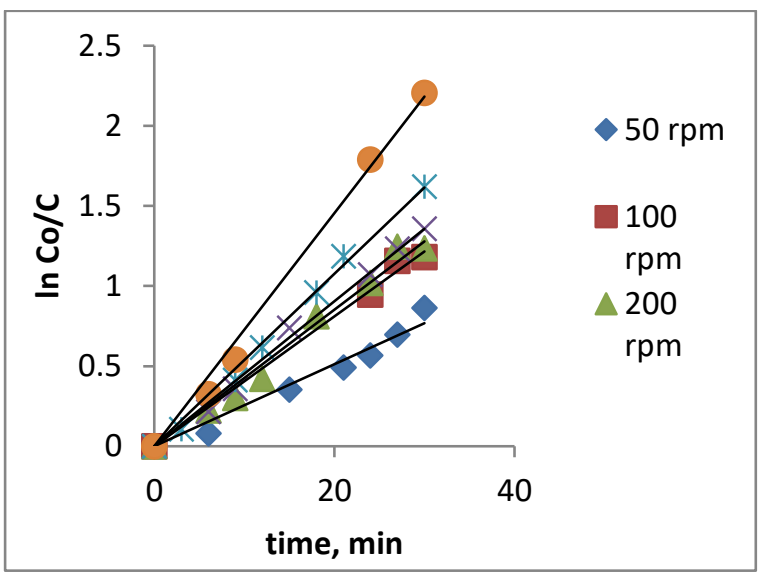

Fig.6. $\ln \mathrm{Co} / \mathrm{C}$ vs. time for $0.4 \%$ fine- pulp consistency at different rpm

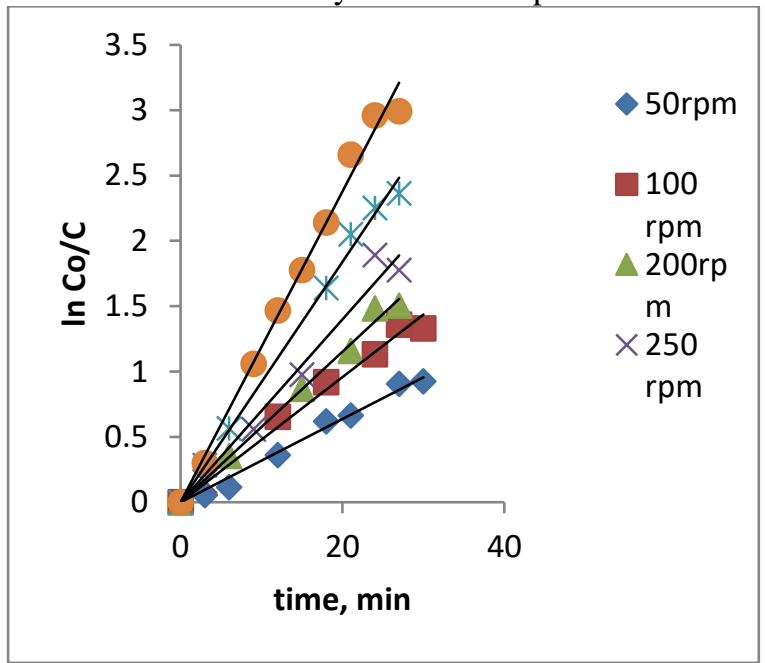

Fig.7. $\operatorname{lnCo} / \mathrm{C}$ vs. time for $0.4 \%$ whole-pulp consistency at different rpm

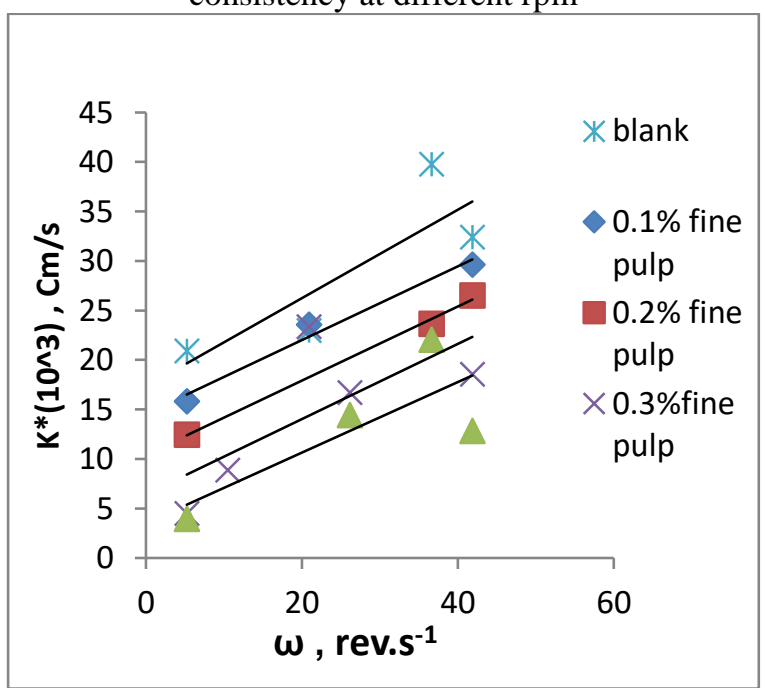

Fig.8. effect of impeller rotational speed on mass transfer coefficient at different whole- pulp consistency 


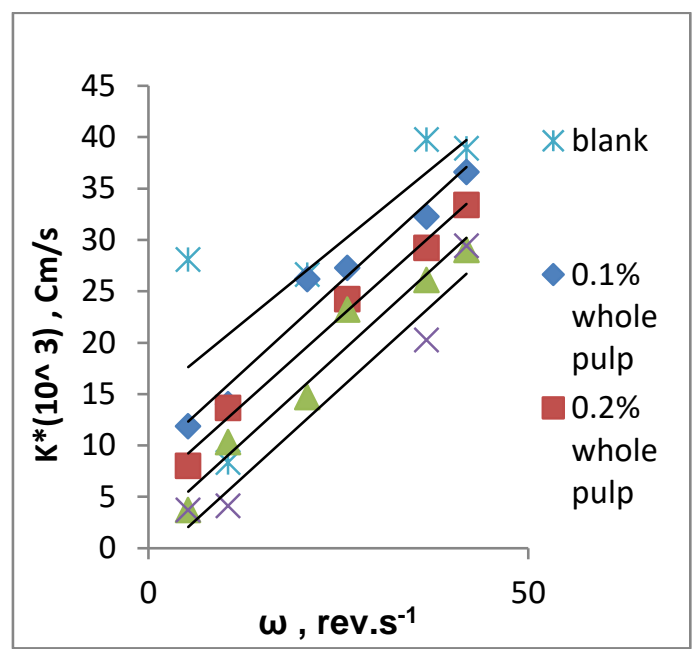

Fig.9. effect of impeller rotational speed on mass transfer coefficient at different fine- pulp consistency

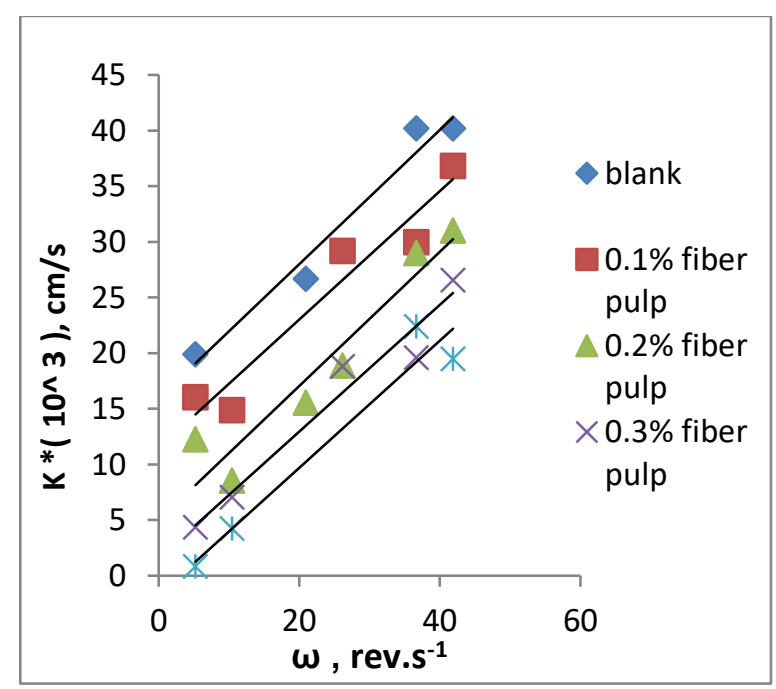

Fig.10. effect of impeller rotational speed on mass transfer coefficient at different fiber- pulp consistency

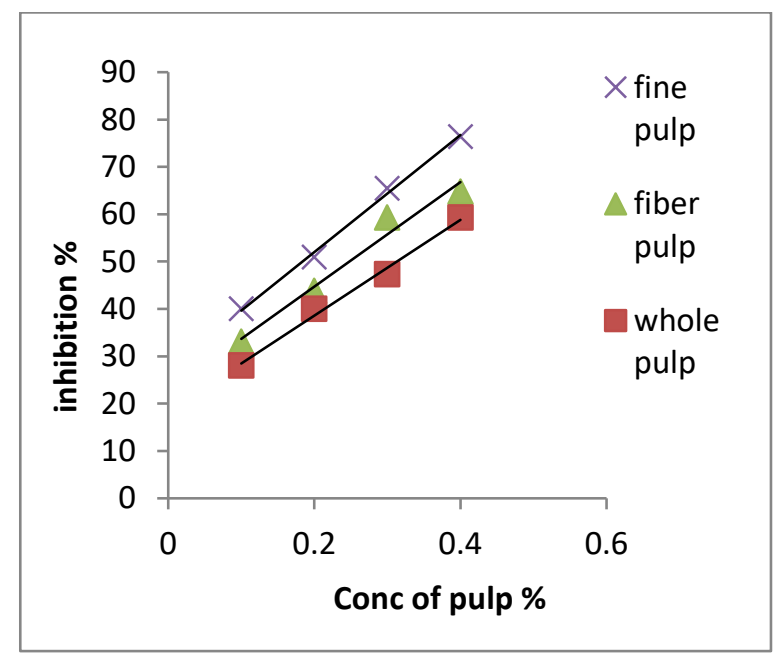

Fig.11. Relation between inhibition $\%$ vs. Conc. $\%$ for different pulp slurry consistency at $400 \mathrm{rpm}$

\section{CONCLUSIONS:}

- $\quad$ The diffusion controlled corrosion of agitated vessel wall was found to decrease in the presence of pulp slurry. The corrosion inhibition efficiency of pulp slurry is a function of pulp slurry types, pulp slurry concentration and agitation speed. The rate of diffusion controlled copper corrosion in acidified dichromate, increased by increasing agitation and decreased by increasing pulp slurry concentration. The percentage of inhibition efficiency ranged from $40 \%$ to $76 \%$ depending on the operating condition, fine-pulp is more effective than whole pulp.

- $\quad$ Fine-pulp slurry was found to cause the highest reduction of mass transfer coefficient, while whole-pulp slurry gives the least reduction of the mass transfer coefficient, this is attributed to the presence of fine in the boundary layer which damp turbulence, thus increasing the hydrodynamic boundary layer thickness with a consequent decrease in the rate of depolarizer diffusion and copper corrosion.

In view of the significant effect of fines-pulp in inhibiting diffusion controlled corrosion in a manner similar to drag reducing polymer, the use of fines-pulp in practice is recommended to inhibit corrosion and reduce mechanical power consumption in equipment operating under turbulent flow such as pipelines, agitated vessels and heat exchangers. Using fine-pulp as a drag reducer would have the advantages that, unlike drag reducing polymer and surfactants, it is mechanically nondegradable and nonpolluting because it can be separated by filtration.

\section{REFERENCES}

[1] Abdel-Aziz M.A. "Solid-liquid mass transfer in relation to diffusion controlled corrosion at the outer surface of helical coil 


\section{Vol. 40, No. 1. January 2021}

immersed in agitated vessels" Chem. Eng. Res. Des. 91, 43-50 (2013).

[2] Amin N.K., Abdel-Aziz M.H., ElAshtoukhy E.S.Z." Effect of pulp-fiber suspensions on the rate of mass transfer controlled corrosion in pipe lines under turbulent flow conditions" Chemical Engineering Research and Design, 92, 2333-2338(2014).

[3] Fadali olfat A., Ebrahiem E.E., Farag T.E., Mahmoud M.S., Obaid M. and Nasser Barakat A.M." Enhancement of mass transfer rate and diminution of the power consumption of copper cementation using electromagnetic field "Energy and Environment Focus, 2, 1-6(2013).

[4] Findlay A.and Kitchener J.K." Practical Physical Chemistry "Longman, London (1965).

[5] Fontana M.G."Corrosion Engineering "Mc Graw Hill, New York (1987).

[6] Greggory D.P. and Riddiford A.C. "Dissolution of copper in sulfuric acid solution" J.Electrochem. Soc., 107,950-956(1960).

[7] Gruber R. and Mclin T. "Mixed Convection in the copper dissolution technique of studying mass transfer" Int. J. Heat Mass Transfer, 46, 2403-2413(2003).

[8] Higgins B.G and Wahern D." Optimum consistency for pumping pulp" TAPPI Journal, 65,131-133(1982).

[9] Hoyt J.W."Turbulent flow of dragreducing suspension "Naval Undersea Center Report TP 299, San Diego (1972).

[10] Huhtanen J.T. and Karvinen RJ."Interaction of non-newtonian fluid dynamics and turbulence on the behavior of pulp suspension flows" Ann. Trans. Nordic Rheol. Sec.13 (2005).

[11] Incropera F.P., Dewitt D.P." Fundamentals of heat and mass transfer " 6th ed, John Wily \&Sons, N.Y. (2005).

[12] Misr Edfo for Pulp, Writing \& Printing Paper Company, Egypt, Personal Communication of mill Manager, 2018.

[13] Nassar ,Mamdouh M."Newsprint from bagasse" $\mathrm{PhD}$ theses, Technical University of Norway, Trondhein, Norway, 1975.

[14] Newaz, Kazi, Md.Salim ; Duffy, Geoffrey; and Chen, Xiao Dong " Heat transfer in the drag reducing regime of wood pulp fiber suspensions " Chemical Engineering Journal 73,241-253(1999).

[15] Patil V.K. and Sharma M.M. "Hydrodynamics and Mass Transfer Characteristics of Co-current down flow packed tube column" Can .J. Chem. Eng., 61,509516(1983).

[16] Pickett, D.J." Electrochemical Reactor Design "Elsevier, N.Y. (1977).

[17] Robertson A.A. and Mason S.G. "The flow characteristics of dilute fiber suspensions" TAPPI Journal, 40, 5,326-334(1957).

[18] Ronald McDonald, Editor" Pulp and Paper Manufacture, vol.II and vol.III" Joint Text Book Committee of the Pulp Industry, N.Y.2nd Ed. (1969).

[19] Rydholm, S.V.H "Pulping Process"Interscience pub., NY,1st Ed, 1967.

[20] Singh, G., et al. (2019). "Biobleaching for pulp and paper industry in India: Emerging enzyme technology."BiocatalysisandAgricultural Biotechnology 17: 558-565.

[21] Steenberg,B., Standgern B. and Wohren D"Studies on pulp crill" Svensk Papperstidning, No 12,395-397(1960).

[22] Sdahmed G.H., Khatab M.A., Mahgob F.M., Al-Azzony M.R."Solid liquid mass transfer at the base of a rectangular agitated vessel" Chem. Eng. Commun., 191,168-181 (2004).

[23] Schmitt G. and Bakalli M. "Advanced models for erosion corrosion and its mitigation" Materials Corrosion, 59, 181-192 (2008).

[24] United Nation, N.Y.(1955)" Pulp and Paper Prospects in Latin America"

[25] Vaseleski R.C and Metzner A.B "Drag reduction in the turbulent flow of fiber suspension "AICHE Journal, 20, 2,301-306(1974).

[26] Walsh F." First course in Electrochemical Engineering- The electrochemical Consultancy" Romsey, UK (1993). 
الملخص:

تمت دراسة تآكل جدار الوعاء المحتوي على معلقات من ألياف اللب باستخدام اختبار سريع يتضمن تحلل النحاس و انتثاره في ثنائي كرومات الحمض. كانت المتغيرات التي تمت دراستها هي معدلات تدفق الياف اللبّ ، وتركيزات الالياف وحجم ألياف اللب. تمت دراسة ثلاثة أحجام مختلفة من اللب ، وهي:لبعجينة الألياف ، لب عجينة الورق ولب عجينة الورق بالكامل. وجد أن معدل تآكل النحاس المتحكم في الانتشاريزداد بزيادة معدل تدفق الالياف وانخفض بزيادة تركيز الياف اللب. تم العثر على الجرامات الموجودة في الياف عجينة الورق لتلعب دورًا رئيسيًا في تقليل معدل التآكل الذي يتم التحكم فيه بواسطة الانتشار نظرًا لقدرته على تقليل الدوامات الصغيرة الحجم على جدار الوعاء بطريقة تثبه سحب البوليمرات المخففة في الأنابيب. تراوحت كفاءة تثبيط النسبة المئوية باستخدام الياف اللب الدقيق من 40 \% إلى 76 ٪ ، في حين تراوحت قيمة الالياف كامل اللب من 28 ٪ إلى 47 \% ، عندما تراوح تركيز الياف اللب من 0.1 \% إلى 0.4 \% 